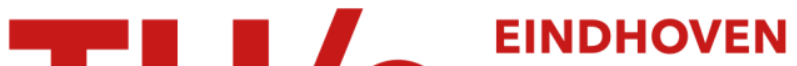

\section{Polymerization of MMA at the surface of inorganic submicron particles}

\section{Citation for published version (APA):}

Caris, C. H. M., van Elven, L. P. M., Herk, van, A. M., \& German, A. L. (1989). Polymerization of MMA at the surface of inorganic submicron particles. British Polymer Journal, 21(2), 133-140.

https://doi.org/10.1002/pi.4980210207

DOI:

10.1002/pi.4980210207

Document status and date:

Published: 01/01/1989

\section{Document Version:}

Publisher's PDF, also known as Version of Record (includes final page, issue and volume numbers)

\section{Please check the document version of this publication:}

- A submitted manuscript is the version of the article upon submission and before peer-review. There can be important differences between the submitted version and the official published version of record. People interested in the research are advised to contact the author for the final version of the publication, or visit the $\mathrm{DOI}$ to the publisher's website.

- The final author version and the galley proof are versions of the publication after peer review.

- The final published version features the final layout of the paper including the volume, issue and page numbers.

Link to publication

\section{General rights}

Copyright and moral rights for the publications made accessible in the public portal are retained by the authors and/or other copyright owners and it is a condition of accessing publications that users recognise and abide by the legal requirements associated with these rights.

- Users may download and print one copy of any publication from the public portal for the purpose of private study or research.

- You may not further distribute the material or use it for any profit-making activity or commercial gain

- You may freely distribute the URL identifying the publication in the public portal.

If the publication is distributed under the terms of Article 25fa of the Dutch Copyright Act, indicated by the "Taverne" license above, please follow below link for the End User Agreement:

www.tue.nl/taverne

Take down policy

If you believe that this document breaches copyright please contact us at:

openaccess@tue.nl

providing details and we will investigate your claim. 


\title{
Polymerization of MMA at the Surface of Inorganic Submicron Particles
}

\author{
Carola H. M. Caris, Louisa P. M. van Elven, Alex M. van Herk \\ \& Anton L. German*
}

Department of Polymer Chemistry, Eindhoven University of Technology, PO Box 513, 5600 MB Eindhoven, The Netherlands

(Received 5 April 1988; revised version received 3 October 1988; accepted 6 October 1988)

\begin{abstract}
Inorganic submicron particles, such as $\mathrm{TiO}_{2}$, were modified with titanate coupling agents. The structure and stability of some titanates, both in solution and at the particle surface, were investigated by various methods. The modified titanium dioxide was dispersed in a solution of sodium dodecylsulphate (SDS) in water. The surfactant adsorbs at the now hydrophobic particle surface, thus creating a micellelike structure with an inorganic particle in the centre. In this system an emulsion polymerization of methyl methacrylate was carried out. Product formed at the particle surface is either physically bound by entanglement or chemically bound by covalent bonding to the titanates. In this way a core-shell morphology is obtained with an inorganic core and a polymer shell. The effects of several reaction parameters on the kinetics of the polymerization were studied. The encapsulated $\mathrm{TiO}_{2}$ particles may offer interesting prospects in those applications where good coupling between polymer matrix and inorganic particles is necessary, such as latex paints and polymer composite materials.
\end{abstract}

Key words: emulsion polymerization, core-shell morphology, encapsulation, titanium dioxide, methyl methacrylate, titanate coupling agents.

\section{INTRODUCTION}

By means of emulsion polymerization processes several types of particles with a core-shell morphology can be obtained. In this paper we describe a way to obtain particles with an inorganic core and a polymer shell by means of an emulsion polymerization like process.

The surface of submicron $\mathrm{TiO}_{2}$ particles is hydrophilic ${ }^{1}$ and contains several acidic $\mathrm{OH}$ groups, which can react with coupling agents such as titanates. These are organic compounds which consist of a central titanium atom, one or two small hydrolysable groups and two or three long organic chains or functional groups. ${ }^{2,3}$ A reaction can take place in which an alcohol is formed, leaving the titanate coupled to the pigment surface. Thus, the hydrophilic surface becomes hydrophobic. The

* To whom correspondence should be addressed. modified $\mathrm{TiO}_{2}$ particles are then dispersed in an aqueous solution of sodium dodecylsulphate (SDS). Now part of the surfactant is adsorbed at the particle surface, as was determined by conductimetric titrations. In this way a micelle like structure is formed with an inorganic particle as a core. In this system an 'emulsion polymerization' with methyl methacrylate is carried out. The initial surfactant concentration is kept at, or slightly above, the CMC in order to prevent polymerization in micelles that do not contain $\mathrm{TiO}_{2}$. The effect of reaction parameters, like concentration of surfactant, $\mathrm{TiO}_{2}$ or initiator, on the kinetics of the polymerization was studied.

The reaction product, inorganic particles encapsulated by polymer, was studied for instance by means of scanning electron microscopy and dark field microscopy. These particles may offer perspectives as pigment in latex paints, where they might

British Polymer Journal 0007-1641/89/\$03.50 (C) 1989 Society of Chemical Industry. Printed in Great Britain 
provide better coupling between pigment and binder (preventing agglomeration of the pigment, thus improving film properties and gloss), and also as fillers for polymer composites and as carriers for catalysts.

\section{EXPERIMENTAL}

The experiments were carried out with pure rutile (Kronos, RLK). This material was washed with water, in order to remove some $\mathrm{K}_{2} \mathrm{SO}_{4}$ adsorbed at the surface, and dried under vacuum at $130^{\circ} \mathrm{C}$ before use. The $z$-average particle diameter was determined with a Malvern Autosizer 2c (dynamic light scattering). The surface composition was studied by means of ESCA (electron scattering for chemical analysis), using an instrument of Physical Electronics Industries Inc. Titanates KR TTS and KR 7 from Kenrich Petrochemicals Inc. were used without further purification. The titanate content, structure and stability against solvolysis were determined by means of ${ }^{1} \mathrm{H}$ and ${ }^{13} \mathrm{C}$ NMR in deuterated chloroform, using a $60 \mathrm{MHz}$ Hitachi Perkin Elmer High Resolution NMR Spectrometer R-24B and a $200 \mathrm{MHz}$ Bruker AC200 instrument.

Modification of $\mathrm{TiO}_{2}$ was carried out in isopropanol (Merck, pro analysi), diethylether (Merck, pro analysi) or dichloromethane (Merck, pro analysi): $30 \mathrm{~g} \mathrm{TiO}_{2}$ and $30 \mathrm{~g}$ glass pearls were added to the flask containing the titanate in the appropriate solvent in a concentration of $1.5-4.5 \mathrm{~g} /$ litre $\left(0.5-1.5 \mathrm{wt} \%\right.$ with regard to $\left.\mathrm{TiO}_{2}\right)$ and the mixture was shaken for about $2 \mathrm{~h}$. Then the glass pearls were removed by filtration and the modified $\mathrm{TiO}_{2}$ was isolated by centrifugation. The product was washed three times with solvent, and then dried at room temperature under vacuum.

The amount of titanate at the surface was determined by elemental analysis (TNO, Zeist, The Netherlands). Stability against solvolysis was studied by means of elemental analysis, UV spectroscopy (using a Hewlett-Packard 8451A Diode Array Spectrophotometer) and conductimetry (using a Radiometer CDM80 Conductivity Meter). The structure of titanates at the particle surface was determined by diffuse reflection FTIR. The adsorption of sodium dodecylsulphate (SDS) at the modified particle surface in dispersions was determined by conductimetric titrations. Sodium dodecylsulphate (Fluka Chemie A.G., puriss > 99\% pure) was used without further purification (twophase titration according to Reid et al. ${ }^{4}$ showed it was over $99.9 \%$ pure).

Polymerizations were carried out with methyl methacrylate (Merck, pro analysi), distilled at reduced pressure under nitrogen to remove the inhibitor. We based our radical initiator on $4,4^{\prime}$-azo- bis(4-cyanopentanoic acid) (Fluka A.G., purum $>97 \%$ pure). Because of its limited solubility in water we decided to use the sodium salt instead of the acid (prepared by reacting the acid with two equivalents of sodium methanolate in methanol). Polymerizations were carried out in a double-walled thermostated $\left(55^{\circ} \mathrm{C}\right)$ reaction vessel, kept under a slight excess pressure of $\mathrm{N}_{2}$. Dispersions of (modified) $\mathrm{TiO}_{2}$ in a solution of sodium dodecylsulphate in water (concentration varying between 2 and $4 \mathrm{~g} /$ litre) were made with an Ystral type X1020 high shear stirrer, and added to the reaction vessel. Then monomer was added and the mixture was flushed with $\mathrm{N}_{2}$ for about $45 \mathrm{~min}$ at $20^{\circ} \mathrm{C}$, in order to remove $\mathrm{O}_{2}$. The mixture was stirred with a magnetic stirrer, kept at about $250 \mathrm{rpm}$, for $30 \mathrm{~min}$ at a temperature of $55^{\circ} \mathrm{C}$ before adding the initiator solution, thus settling the equilibrium. The reaction vessel was equipped with a $10 \mathrm{ml}$ addition funnel from which extra monomer, soap or initiator solutions were added dropwise to the reaction mixture. Samples (c. $0.2 \mathrm{ml}$ ) were taken every 1 or $2 \mathrm{~min}$ during the entire course of the polymerization, through a septum in the reaction vessel, using a syringe. After each sampling the septum was capped to prevent any possible leakage. Samples were diluted with $c .2 \mathrm{ml}$ distilled water, containing some hydroquinone to stop the reaction. Conversion was determined by gas chromatography, with isopropanol (Merck, p.a.) as an internal standard in the reaction mixture. Gas chromatograph: Hewlett-Packard 5890; 1/8 inch polyphenylether packed column; column temperature $80^{\circ} \mathrm{C}$; injection port temperature $100^{\circ} \mathrm{C}$; FID temperature $150^{\circ} \mathrm{C}$; carrier gas $\mathrm{N}_{2}$.

All reactions were carried out in demineralized water; some systems were buffered at $\mathrm{pH}=8.00$ (Titrisol: borate $/ \mathrm{HCl}$ ) or at $\mathrm{pH}=5.00$ (Titrisol: citrate $/ \mathrm{NaOH}$ ).

Polymerization products were studied in emulsion by dark field microscopy and after drying on a steam bath, by scanning electron microscopy.

\section{RESULTS AND DISCUSSION}

\section{Structure and stability of titanates}

The surface of the rutile used has been proven to consist of pure $\mathrm{TiO}_{2}$ by means of ESCA. The average particle diameter appeared to be $260 \mathrm{~nm}$. Structure and stability of some titanates in solution were studied by means of ${ }^{1} \mathrm{H}$ and ${ }^{13} \mathrm{C}$ NMR. Figure 1 shows the ${ }^{1} \mathrm{H}$ NMR spectrum of tetraisopropyltitanate in deuterated chloroform. The septet at $4 \cdot 47 \mathrm{ppm}$ is caused by $\mathrm{H}^{a}$. The ratio $\mathrm{H}^{a}: \mathrm{H}^{b}=1: 6$, as was expected.

Figure 2 shows the ${ }^{1} \mathrm{H}$ NMR spectrum of $\mathrm{KR}$ $\mathrm{TSS}^{\circledR}$, which, according to Kenrich, ${ }^{3,5}$ consists of 


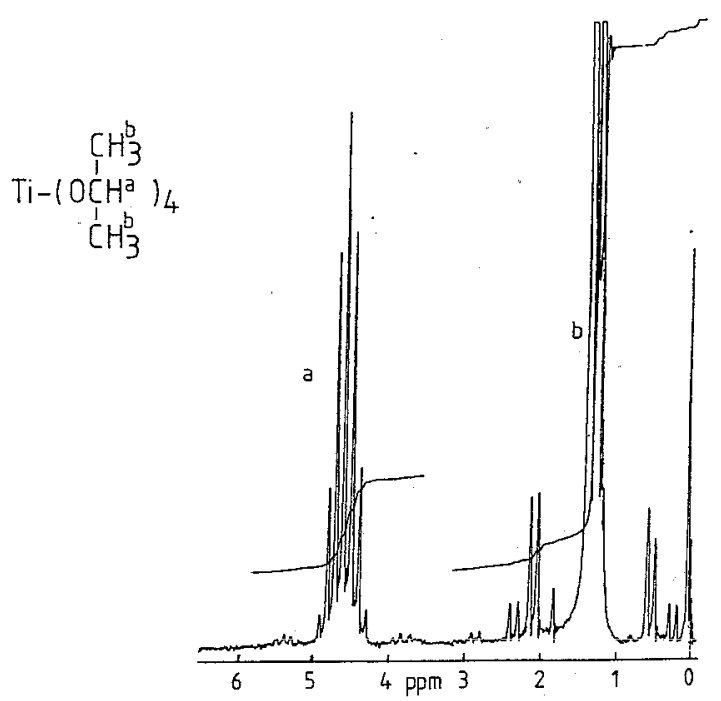

Fig. 1. $60 \mathrm{MHz}{ }^{1} \mathrm{H}$ NMR spectrum of tetraisopropyltitanate in deuterated chloroform.

$95 \%$ isopropyl triisostearoyl titanate and 5\% isopropanol as a solvent. As the molecular weight of isopropyl triisostearoyl titanate is $957424 \mathrm{amu}, 5 \%$ of isopropanol is exactly one equivalent. However, from the spectrum it can be seen that the signal of isopropanol at $3.8 \mathrm{ppm}$ fails to appear. Instead the ratio $\mathrm{H}^{a}$ :other protons is $1: 62$. Thus it can be concluded that KR TTS ${ }^{\circledR}$ censists of $72 \%$ diisopropyl diisostearoyl titanate and $28 \%$ isostearoic acid. After adding on purpose another equivalent of isopropanol to a solution of KR TTS ${ }^{\circledR}$ in chloroform, further solvolysis occurred almost immediately, resulting in a mixture of diisopropyl diisostearoyl titanate, triisopropyl isostearoyl titanate, isostearoic acid and only a negligible amount of isopropanol (Fig. 3).

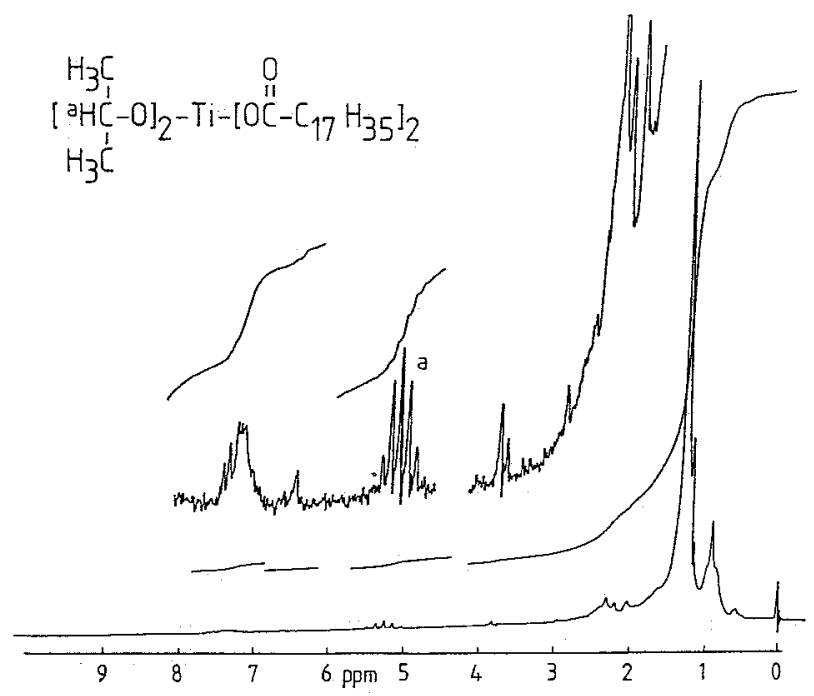

Fig. 2. $60 \mathrm{MHz}^{1} \mathrm{H}$ NMR spectrum of $\mathrm{KR}^{\mathrm{T}} \mathrm{TS}^{\circledR}$ in deuterated chloroform.

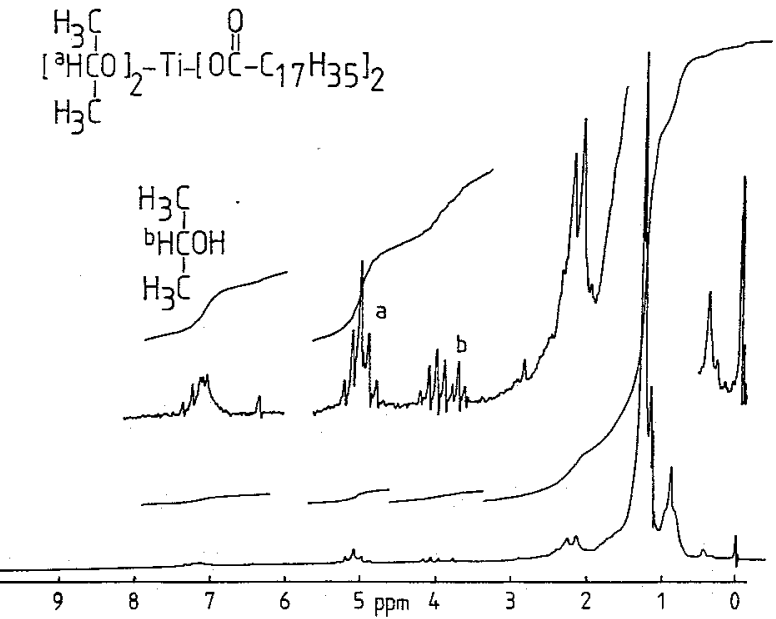

Fig. 3. $60 \mathrm{MHz}{ }^{1} \mathrm{H}$ NMR spectrum of $K R T_{T S}{ }^{\circledR}$ in deuterated chloroform, after adding on purpose another equivalent of isopropanol.

Similar results were obtained for KR $7^{\circledR}$, which, according to Kenrich, ${ }^{3,6}$ consists of $88 \%$ isopropyl dimethacryl isostearoyl titanate, $10 \%$ isopropanol (solvent) and $2 \%$ methacrylic acid. Here too, the alleged amount of isopropanol is one equivalent, and the amount of methacrylic acid $0 \cdot 15$ equivalents. From Fig. 4 it can be seen that in KR $7^{\circledR}$ there are two doublets (at 5.95 and at $5.55 \mathrm{ppm}$ ) in a ratio $1 \cdot 16: 1 \cdot 00$. The doublet at $5 \cdot 95 \mathrm{ppm}$ is caused by free methacrylic acid. There is hardly any free isopropanol present, and the ratio isopropyl:methacryl appears to be $2: 1$. From this it can be concluded that KR $7^{\circledR}$ contains diisopropyl methacryl isostearoyl titanate and methacrylic acid. From the signal at 1.2 ppm it can be seen that KR $7^{\circledR}$ also contains free isostearoic acid.

On these grounds a comparison was made between the effectiveness of modifying $\mathrm{TiO}_{2}$ with

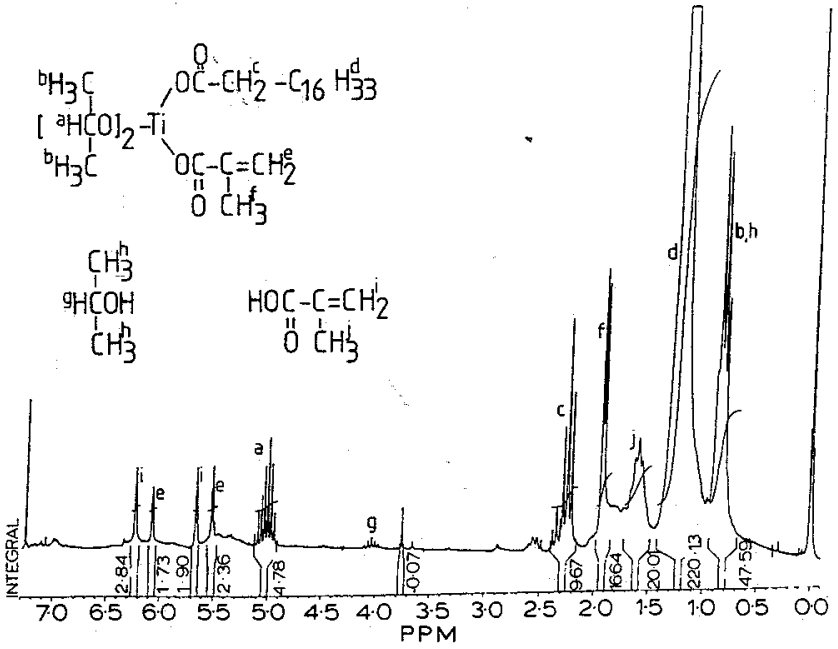

Fig. 4. $200 \mathrm{MHz}{ }^{1} \mathrm{H}$ NMR spectrum of KR $7^{\oplus}$ in deuterated chloroform. 


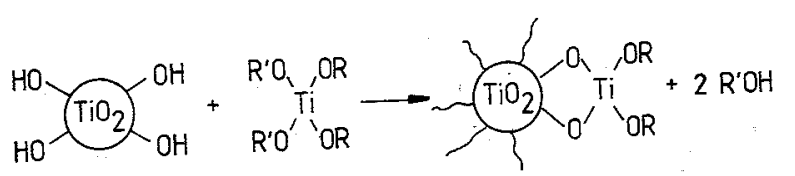

Fig. 5. Modification of $\mathrm{TiO}_{2}$ with titanates.

$\mathrm{KR} \mathrm{TTS}^{\circledR}$ or $\mathrm{KR}^{\circledR}$ in isopropanol, in diethylether and in dichloromethane, respectively. Coupling is assumed to proceed according to the mechanism postulated by Monte and Sugerman ${ }^{3}$ (Fig. 5).

From the UV spectrum in Fig. 6 it can be seen that addition of water to a solution of titanate in isopropanol causes hydrolysis of part of the titanate molecules. Adding $\mathrm{TiO}_{2}$ even appears to enhance hydrolysis. Probably the particle surface catalyses hydrolysis by water adsorbed at the surface.

From elemental analysis it appeared unambiguously that isopropanol itself causes solvolysis of the titanate, when $\mathrm{TiO}_{2}$ is modified with a titanate in isopropanol in contrast to the modification in diethylether (Fig. 7). This behaviour has already been strongly suggested by the NMR measurements presented above.

Surprisingly, Kenrich recommends isopropanol as a solvent for the modification of inorganic particles with titanates, but our results indicate that protic solvents lead to rapid solvolysis of the titanates and therefore should be avoided. In aprotic solvents, such as chloroform, dichloromethane or diethylether, better results can be obtained.

The presence of titanate at the $\mathrm{TiO}_{2}$ surface was established not only by elemental analysis but also by diffuse reflection FTIR (Figs. 8 and 9). From these results it can be concluded that, under the appropriate conditions, it is possible to establish a covalent bond between the $\mathrm{TiO}_{2}$ surface and a titanate, providing the possibility of attaching a functional group (like the methacrylic group) to the particle surface.

Since the titanate-modified particles have to be dispersed in water for the 'emulsion polymerization'

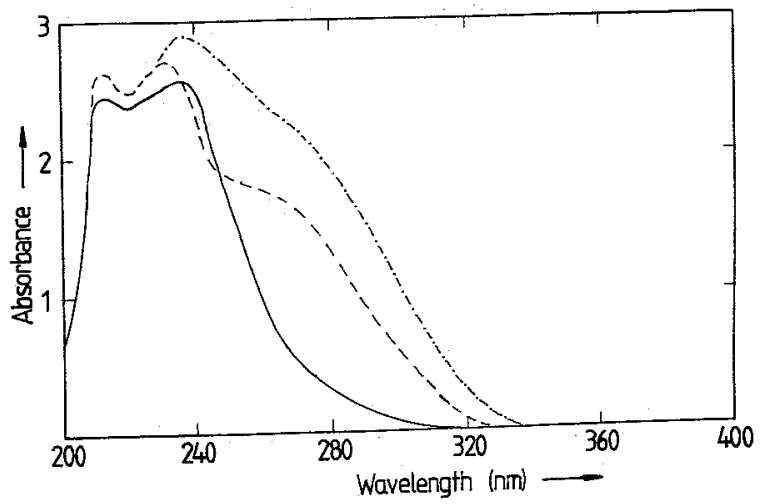

Fig. 6. Hydrolysis of titanates: —— in isopropanol; - - - after addition of water;-.-.-- after addition of $\mathrm{TiO}_{2}$ particles.

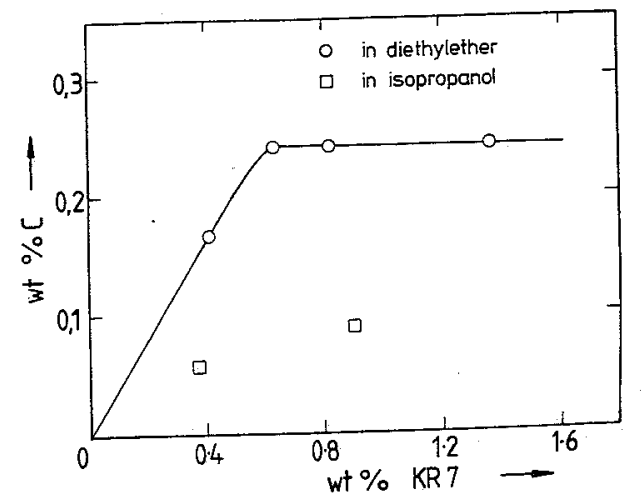

Fig. 7. Elemental analysis of $\mathrm{TiO}_{2}$ modified with various amounts of KR $7^{\circledR}$. Dispersion by conventional stirring. Higher levels (approx. $0.6 \mathrm{wt} \% \mathrm{C}$ ) were obtained using the presently described, improved dispersion method.

process, the sensitivity of the titanate bonding towards hydrolysis had to be investigated. $\mathrm{TiO}_{2}$ was modified with various amounts of KR TTS ${ }^{\circledR}$ and dispersed in water. In a conductimetric titration SDS was added. It appeared (see Fig. 10) that SDS was adsorbed at the particle surface by the titanates, the amount of adsorbed SDS being a function of the titanate content of the particles. By the adsorption of SDS at the modified, now hydrophobic, $\mathrm{TiO}_{2}$ surface the dispersion was stabilized against coagulation. The same titration was carried out after the dispersion had been heated at $60^{\circ} \mathrm{C}$ for $1 \mathrm{~h}$. Only at
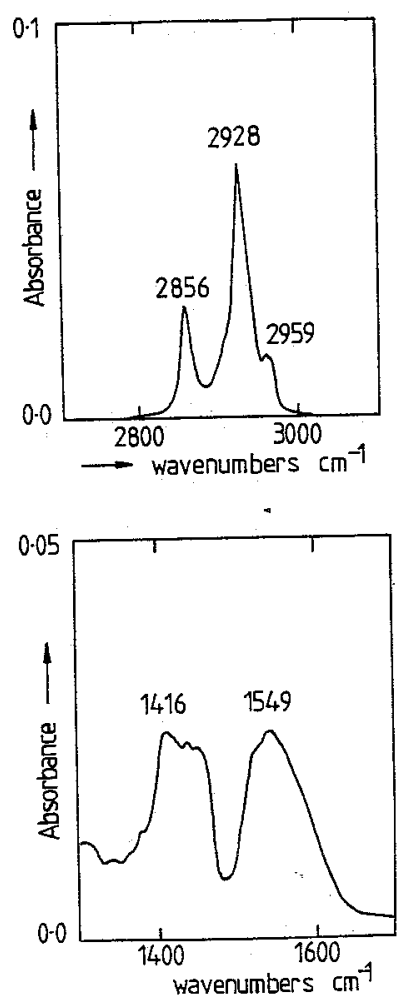

Fig. 8. Diffuse reflection FTIR spectra of the isostearate group in KR TTS ${ }^{\oplus}$ at the surface of $\mathrm{TiO}_{2}$.

BRITISH POLYMER JOURNAL VOL. 21, NO. 2, 1989 

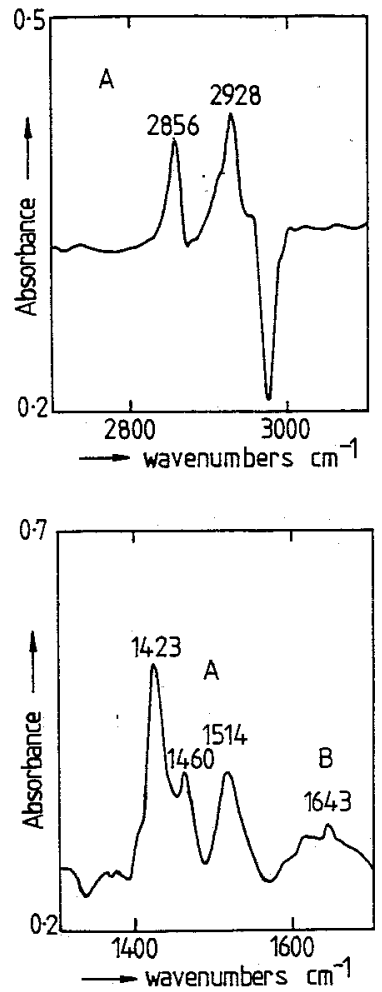

Fig. 9. Diffuse reflection FTIR spectra of $\mathrm{TiO}_{2}$, modified with KR $7^{\circledR}$ : A, Signals of the isostearate group; $B$, signal of the methacrylic group.

low titanate contents, hydrolysis appeared to have occurred, resulting in a 'negative' adsorption, apparently because of a cosurfactant like behaviour of the hydrolysed isostearoic acid. At titanate contents over $0.7 \mathrm{wt} \%$ the two curves in Fig. 10 coincide, indicating a selfprotecting effect of the titanates against hydrolysis. Obviously, under those conditions surface groups inducing hydrolysis are absent or sufficiently shielded, while the hydrophobic mantle has sufficient density to repel water effectively from the hydrolysable moieties near the particle surface.

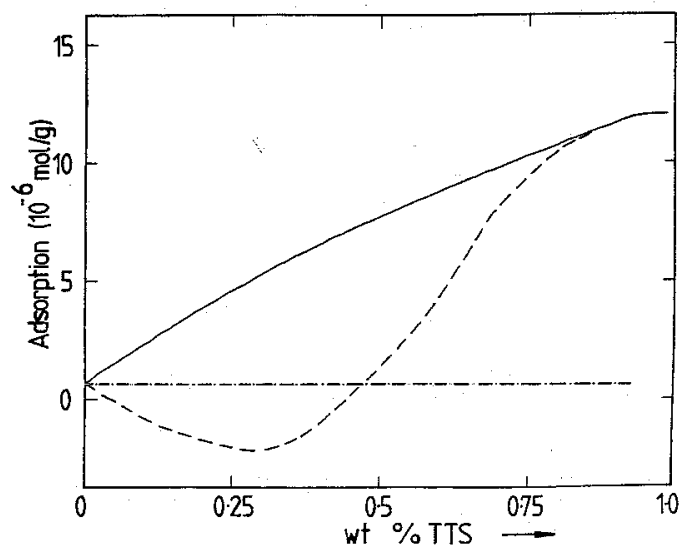

Fig. 10. Adsorption of SDS at the particle surface, as a function of the titanate content of the particles $\left(66-67 \mathrm{~g} \mathrm{TiO}_{2}\right.$ per litre, $1.0 \mathrm{wt} \% \mathrm{KR}$ TTS): $-20^{\circ} \mathrm{C} ;---60^{\circ} \mathrm{C}, 1 \mathrm{~h}$.
From these experiments it can be concluded that a micelle-like structure can be formed at the particle surface, and will remain stable against hydrolysis under polymerization conditions if the $\mathrm{TiO}_{2}$ has been modified with more than $0.7 \mathrm{wt} \%$ of titanate in an aprotic solvent.

\section{Polymerization of methyl methacrylate at the surface of modified $\mathrm{TiO}_{2}$}

Methyl methacrylate (MMA) is polymerized in dispersions of $\mathrm{TiO}_{2}$ (modified with KR TTS ${ }^{\circledR}$ in dichloromethane using glass pearls), which is stabilized against coagulation by SDS. Monomer can be adsorbed both in normal micelles and in 'micelles' containing a $\mathrm{TiO}_{2}$ particle in the core. In order to prevent polymerization in normal micelles the initial SDS concentration of all experiments is kept at values close to the CMC. Polymerization is started by a water soluble initiator (sodium $4,4^{\prime}$-azobis(4-cyanopentanoate)) and will take place in the 'micelles' at the surface of the $\mathrm{TiO}_{2}$ particles (similar to a normal emulsion polymerization). Polymer formed at the modified particle surface will become physically bound to the $\mathrm{TiO}_{2}$ by entanglements with the titanate chains and by adsorption. It can become chemically bound by means of chain transfer to titanates or by copolymerization with a titanate containing monomeric moieties (for instance $\mathrm{KR}$ $\left.7^{\circledR}\right)$. The result may be a particle consisting of an inorganic core and a polymer shell (Fig. 11).

The effect of the presence of $\mathrm{TiO}_{2}$ on the polymerization behaviour is demonstrated in Fig. 12. Unmodified $\mathrm{TiO}_{2}$ has only a negligible effect on the conversion-time curve as compared with the $\mathrm{TiO}_{2}$ free emulsion polymerization of MMA. However, unmodified $\mathrm{TiO}_{2}$ particles do not become encapsulated and their dispersion will not be stable for more than about 1 day. Only the presence of modified $\mathrm{TiO}_{2}$ particles during polymerization appears to lead to interesting phenomena. Figure 12 suggests that after stage I a sharp but temporary decrease in polymerization rate occurs giving rise to
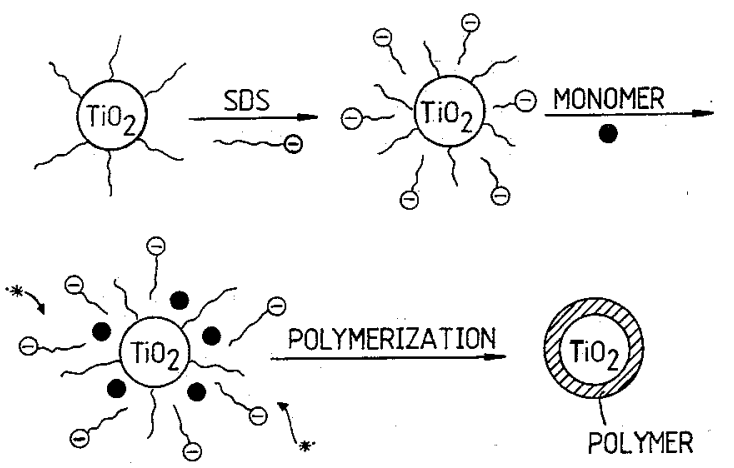

Fig. 11. 'Emulsion' polymerization at the surface of a $\mathrm{TiO}_{2}$ particle $(*=$ radical $)$. 


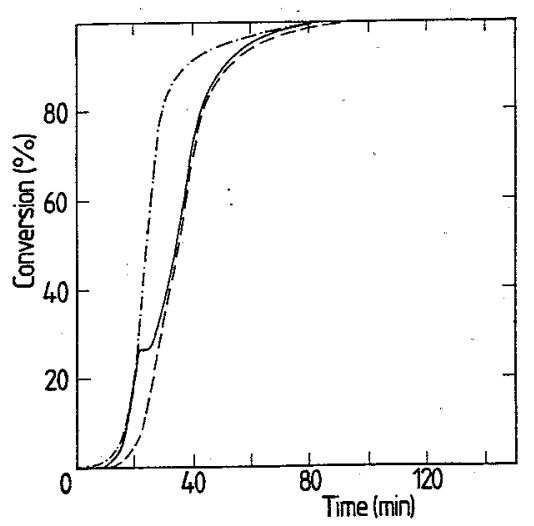

Fig. 12. Effect of the presence of (modified) $\mathrm{TiO}_{2}$ on conversion-time plots of MMA polymerization: -.-. MMA; MMA:TiO $2 / 1 \cdot 204 \% \mathrm{KR}_{\text {TTS }}{ }^{\circledR}=3: 1 ;--\mathrm{MMA}_{\mathrm{TiO}_{2}}=3: 1$.

a plateau in the conversion-time curve. The conversion at which this occurs depends upon the ratio $\mathrm{MMA}_{\mathrm{TiO}}$, as shown in Fig. 13.

The slowdown is not affected by $\mathrm{pH}$ : polymerizations at $\mathrm{pH}=5.00$ or 8.00 show similar kinetic behaviour (Fig. 14).

At higher SDS concentrations no temporary decrease in polymerization rate was observed, as shown in Fig. 15. Also, if extra SDS is added during stage I of the polymerization no plateau occurs.

Similar conversion-time plots were observed in the polymerization of vinyl chloride ${ }^{7,8}$ and vinylidene chloride. $^{9-13}$ In the two latter cases the polymers obtained are not soluble and hardly swellable in their own monomer. Therefore, polymerization can only take place at the surface of the growing polymer particles. Though PMMA is soluble in MMA, in our system polymerization can only take place at the surface of the particle because no monomer can penetrate into its $\mathrm{TiO}_{2}$ centre. The explanation for the temporary slowdown in overall reaction rate, as suggested by Evans et al., ${ }^{11}$ may be a

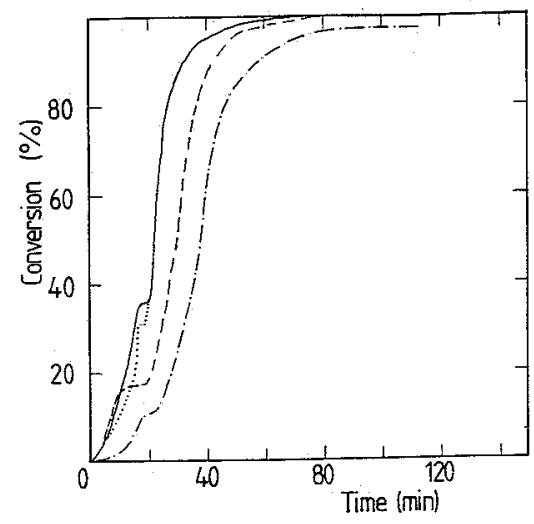

Fig. 13. Effect of the amount of $\mathrm{TiO}_{2} / 1 \cdot 41 \% \mathrm{KR} \mathrm{TTS}^{\circledR}$ on the kinetics of emulsion polymerization of MMA: $\mathrm{TiO}_{2}: \mathrm{MMA}=0 \cdot 5: 3 ; 2 \cdot 37 \mathrm{~g} \mathrm{SDS} /$ litre; $\cdots \cdots \mathrm{TiO}_{2}: \mathrm{MMA}=1: 3$; $2.51 \mathrm{~g}$ SDS/litre; -- $\mathrm{TiO}_{2}: \mathrm{MMA}=1.5: 3 ; 2.63 \mathrm{~g}$ SDS/litre; -... $\mathrm{TiO}_{2}: \mathrm{MMA}=2: 3 ; 2 \cdot 71 \mathrm{~g} \mathrm{SDS} /$ litre.

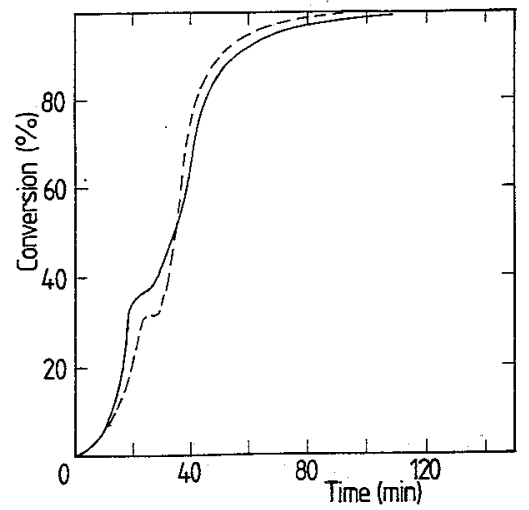

Fig. 14. Effect of $\mathrm{pH}$ on polymerization kinetics $\left(\mathrm{MMA}: \mathrm{TiO}_{2}=3: 1 ;[\mathrm{SDS}]=2 \cdot 40 \mathrm{~g} /\right.$ litre $):-\mathrm{pH}=5.00 ;---$ $\mathrm{p} \overline{\mathrm{H}}=8 \cdot 00$.

sudden change in the availability of monomer, caused by coalescence of monomer droplets, combined with a high intrinsic reaction rate as a result of the possibility of having more than one radical in a growing polymer particle simultaneously. The latter possibility certainly has to be taken into account, because here radicals cannot be expected to diffuse freely through the particle. This may cause a very high intrinsic reaction rate at the particle surface and therefore transport of monomer to growing particles might become rate determining as soon as the monomer droplet surface decreases as the result of coalescence. Coalescence of monomer droplets occurs just after stage $I$, when a deficiency of surfactant arises, because the growing particles need more soap to remain stabilized. The slowdown thus might result from monomer starvation, caused by slow diffusion of monomer from the coalesced monomer droplets to the loci of polymerization. After a while polymer particles may become so much larger that monomer coalescence cannot compensate for the surfactant deficiency. As a consequence,

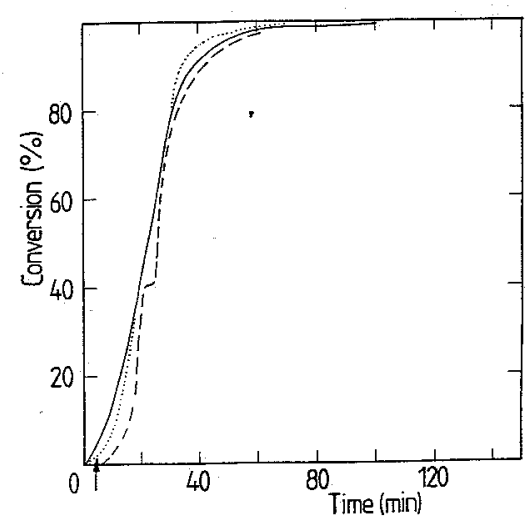

Fig. 15. Effect of surfactant concentration on reaction kinetics, $\mathrm{MMA}: \mathrm{TiO}_{2} / 1 \%$ TTS $=3: 1:---[\mathrm{SDS}]=2 \cdot 4 \mathrm{~g} /$ litre; $[\mathrm{SDS}]=3.5 \mathrm{~g} /$ litre $; \cdots \cdot \cdot \mathrm{SDS}]=2.5 \mathrm{~g} /$ litre after addition of extra SDS at the arrow (reaction was started at [SDS] = $2 \cdot 04 \mathrm{~g} /$ litre). 


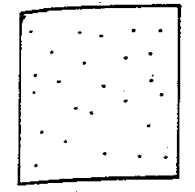

$0 \%$

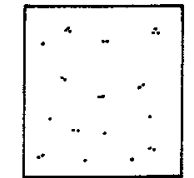

$10 \%$

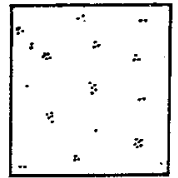

$50 \%$

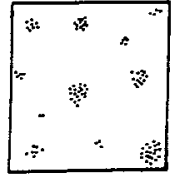

$90 \%$
Fig. 16. Coagulation of polymer/ $\mathrm{TiO}_{2}$ particles during polymerization, studied by dark field microscopy.

repulsive forces between monomer droplet and polymer particle might be reduced, allowing more collisions between them. During these collisions monomer may be directly transferred to the particles, resulting in a recovery of polymerization rate. During polymerization also some coagulation of growing polymer $/ \mathrm{TiO}_{2}$ particles will occur, as can be concluded from dark field microscopy (Fig. 16). However, the separate encapsulated $\mathrm{TiO}_{2}$ particles remain distinguishable in these agglomerates. Apparently, the encapsulation by polymethyl methacry- late prevents the massive agglomeration observed with unmodified $\mathrm{TiO}_{2}$ particles.

The effect of encapsulating pigment particles with polymer as described above is demonstrated in Fig. 17(A)-(D). At a high PMMA: $\mathrm{TiO}_{2}$ ratio (when also free polymer is formed) the encapsulated $\mathrm{TiO}_{2}$ particles precipitate upon drying on a steam bath. During SEM PMMA decomposes as a result of charging by the electron beam (already at $10 \mathrm{kV}$ ). This can be seen from Fig. 17(A), which is a photograph of the top product after drying. It contains less $\mathrm{TiO}_{2}$ than the bottom product of Fig. 17(B). Obviously there the electrons are absorbed by the $\mathrm{TiO}_{2}$ in the core of the polymer particles, that now remain stable under the electron beam. At a ratio $\mathrm{PMMA}: \mathrm{TiO}_{2}=1 \cdot 2: 1$ all polymer is formed at the $\mathrm{TiO}_{2}$ surface, resulting in a homogeneous product after drying (Fig. 17(C) and (D)), and here too PMMA remains stable, thus providing an easy criterion of core-shell morphology. Another interesting phenomenon is that our reaction product is stable against agglomeration for a long time, in
(A)

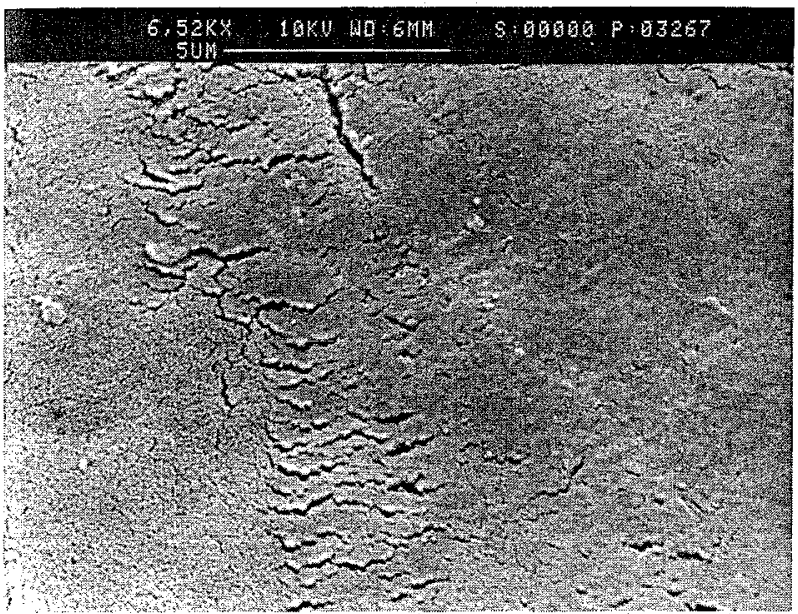

(C)

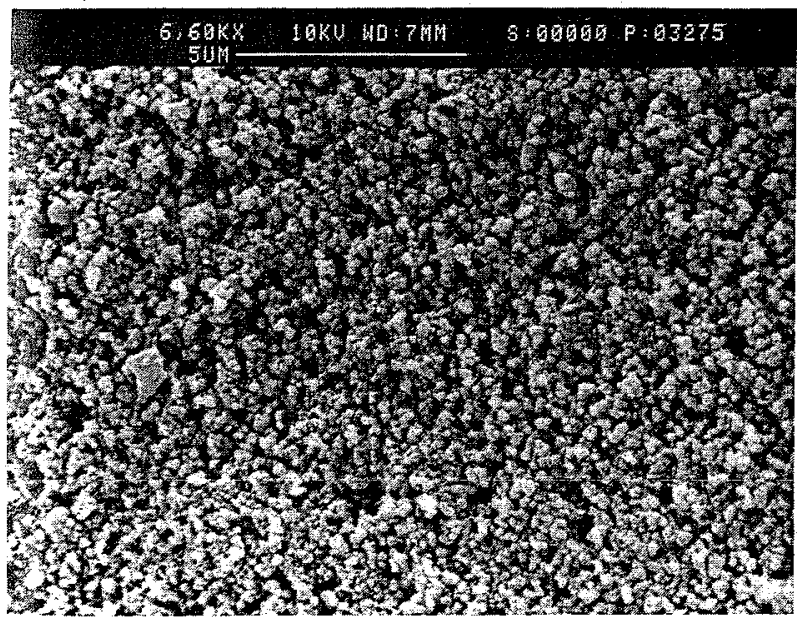

(B)

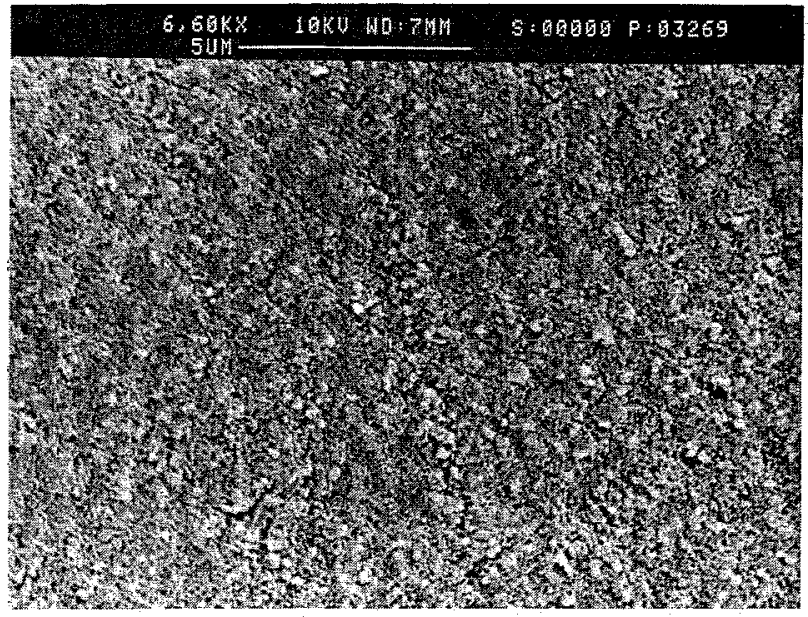

(D)

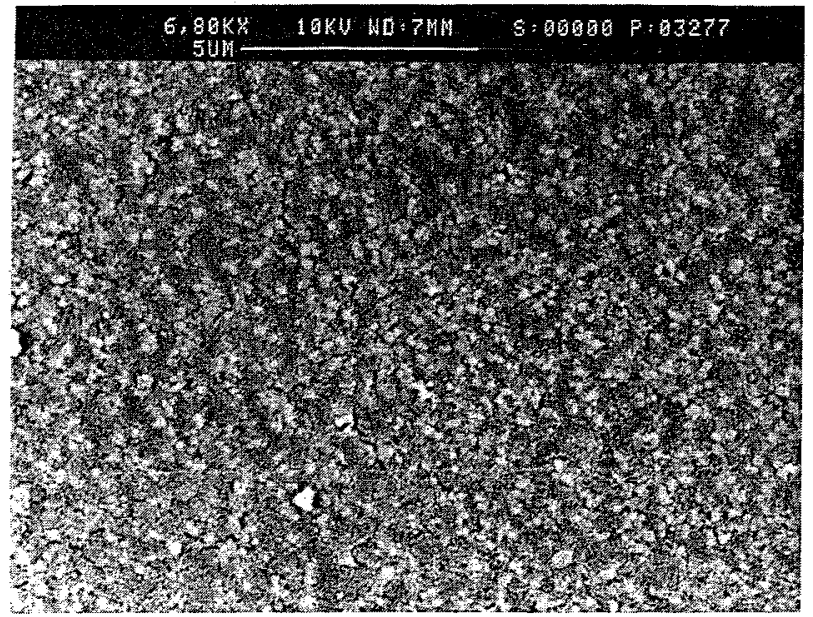

Fig. 17. SEM photographs of polymerization products after drying on a steam bath: A, PMMA:TiO $/ 1 \% \mathrm{KR} \mathrm{TTS}{ }^{\circledR}=1 \cdot 5: 1 \cdot 0$, top product; B, PMMA:TiO $2 / 1 \%$ KR TTS ${ }^{\oplus}=1 \cdot 5: 1 \cdot 0$, bottom product; C, PMMA:TiO $/ 1 \%$ KR TTS ${ }^{\circledR}=1 \cdot 2: 1 \cdot 0$, top product; D, $\mathrm{PMMA}: \mathrm{TiO}_{2} / 1 \% \mathrm{KR} \mathrm{TTS}^{\circledR}=1 \cdot 2: 1 \cdot 0$, bottom product. 
contrast with either dispersions of non-modified $\mathrm{TiO}_{2}$ in polymer emulsions or of modified $\mathrm{TiO}_{2}$ added after polymerization was completed.

\section{CONCLUSIONS}

The structure of two commercially available titanates was determined by means of NMR and appeared to differ from the alleged composition: KR TTS $^{\circledR}$ contains diisopropyl diisostearoyl titanate, and $\mathrm{KR} 7^{\circledR}$ contains diisopropyl methacryl isostearoyl titanate. Titanates can be solvolysed very easily. But if more than $0.7 \mathrm{wt} \%$ of titanate with regard to $\mathrm{TiO}_{2}$ is added to the $\mathrm{TiO}_{2}$ particles in an aprotic solvent, the covalently bound hydrophobic titanate chains will protect themselves against hydrolysis when dispersing the modified $\mathrm{TiO}_{2}$ in water. When modified pigment is dispersed in an aqueous solution of an anionic surfactant (like SDS) dispersion polymerization can be carried out at the surface of the pigment particles showing some kinetic characteristics of those emulsion polymerization systems where the polymers do not dissolve in their own monomers. The polymerization product consists of particles containing an inorganic core and a polymer shell, and of homogeneous polymer particles, their ratio being dependent upon the ratio monomer: $\mathrm{TiO}_{2}$. At a monomer: $\mathrm{TiO}_{2}$ ratio of about 1:1 only encapsulated $\mathrm{TiO}_{2}$ particles are formed. These particles exhibit long term stability against agglomeration. The present method of preparing inorganic core-polymer shell particles offers interesting perspectives, not only in latex paints, but also in, for example, polymer composites and catalyst supports.

\section{ACKNOWLEDGEMENT}

The authors would like to acknowledge financial support from The Netherlands organization 'Onder. zoekstimuleringscommissie Verf' (OSV).

\section{REFERENCES}

1 Solomon, D. H. \& Hawthorne, D. G., Chemistry of Pigments and Fillers, 1st edition. John Wiley \& Sons, New York, 1983.

Monte, S. J. \& Sugerman, G., Polym. Eng. Sci., 24 (18)(1984) 1369-82.

3 Monte, S. J. \& Sugerman, G., Keñ-React Reference Manual;

Titanate and Zirconate Coupling Agents. Kenrich Petrochemicals, Inc., Bayonne, USA, 1985.

4 Reid, V.W., Longman, G. F. \& Heinerth, E., CIA-Report; Tenside 4; Vol. 9 (1967) 292-304.

5 Kenrich Petrochemicals, Inc., Ken-React Titanate Coupling Agent KR TTS Product Data Sheet and Material Safety Sheet.

6 Kenrich Petrochemicals, Inc., Ken-React Titanate Coupling Agent KR 7 Product Data Sheet and Material Safety Sheet.

7 Cotman, Jr, J. D., Gonzalez, M. F. \& Claver, G. C., J. Polym. Sci. Part A-1, 5 (1967) 1137-64.

8 Ugelstad, J., Lervik, H., Gardinovachi, B. \& Sund, E., Pure Appl. Chem., 26 (2) (1971) 121-52.

9 Hay, P. M., Light, J. C., Marker, L., Murray, R. W., Santonicola, A. T. Sweeting, O. J. \& Wepsic, J. G., J. Appl. Polym. Sci., 13 (1961) 23-30.

10 Light, J. C., Marker, L., Santonicola, A. T. \& Sweeting, O. J., J. Appl. Polym. Sci., 13 (1962) 31-8.

11 Evans, C.P., Hay, P. M., Marker, L., Murray, R. W. \& Sweeting, O. J., J. Appl. Polym. Sci., 13 (1962) 39-47.

12 Marker, L., Sweeting, O. J. \& Wepsic, J. G., J. Polym. Sci., 57 (1962) 855-66.

13 Blackley, D. C., Emulsion Polymerization. Theory and Practice, 1 st Edition. Applied Science, London, 1975, p. 469. 